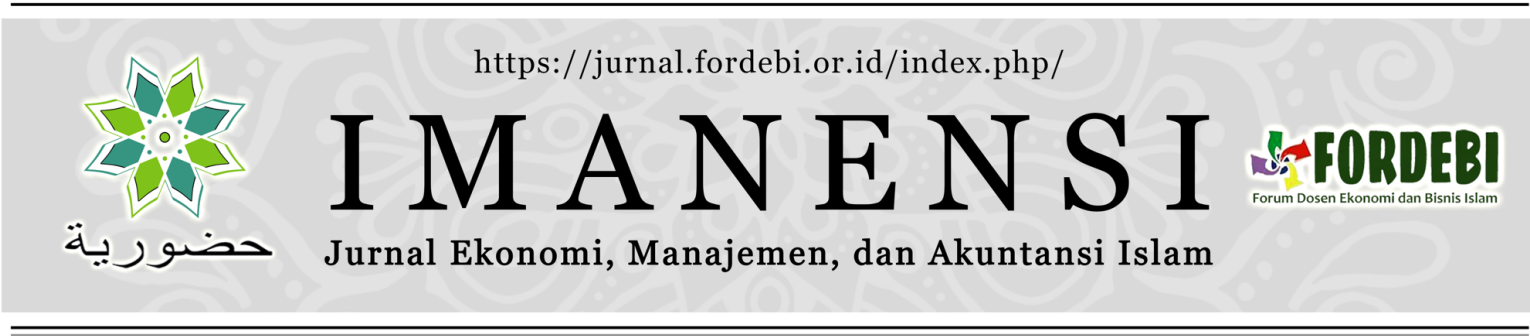

\title{
APAKAH FLEXIBLE PROCESS WORKFLOW BERPERAN MENENTUKAN NILAI PUBLIK?
}

\author{
Alviony Intaniaa,1, Sri Rahayu ${ }^{b, 2^{*}}$, Ratih Kusumastutic,3 \\ a,b,c Universitas Jambi , Jl. Lintas Jambi - Muara Bulian Km. 15, Mendalo Darat, Muaro Jambi, \\ 36361, Indonesia \\ 1aintania764@gmail.com; 2sri_rahayu@unja.ac.id*; ${ }^{3}$ ratihkusumastuti@unja.ac.id \\ *Corresponding author
}

\begin{tabular}{|c|c|}
\hline $\begin{array}{l}\text { INFO ARTIKEL } \\
\text { IMANENSI }\end{array}$ & $\begin{array}{l}\text { Abstrak: Apakah Flexible Process } \text { Workflow } \text { Berperan } \\
\text { menentukan Nilai Publik?. Penelitian ini mengkaji pengaruh }\end{array}$ \\
\hline Volume 6 & tingkat improve situation, capability level of actors, dan flexible \\
\hline Nomor 2 & process workflow terhadap nilai publik. Regresi linier berganda \\
\hline Halaman 77-88 & dipergunakan sebagai metode, dengan responden terpilih adalah \\
\hline $\begin{array}{l}\text { Malang, September } 2021 \\
\text { ISSN: } 2339-1847 \\
\text { e-ISSN: 2683-9968 }\end{array}$ & $\begin{array}{l}\text { masyarakat yang pernah melakukan pengurusan izin dan } \\
\text { memanfaatkan e-government di Kota Sungai Penuh. Hasil } \\
\text { penelitian membuktikan nilai publik dari proyek e-government }\end{array}$ \\
\hline Kronologi Artikel: & dipengaruhi oleh improve situation dan capability level of actors. \\
\hline Tanggal Masuk: & flexible process workflow tidak dapat mempengaruhi nilai publik. \\
\hline 11 Maret 2021 & Hasil penelitian ini menemukan bahwa partisipasi masyarakat \\
\hline Tanggal Revisi: & dibutuhkan proyek e-government. Partisipasi ini bukan hanya \\
\hline 16 Agustus 2021 & dalam penggunaan tetapi sebaiknya juga pada tahap \\
\hline $\begin{array}{l}\text { Tanggal Diterima: } \\
22 \text { Agustus } 2021\end{array}$ & perencanaan dan pengembangan. \\
\hline $\begin{array}{l}\text { Kata Kunci: } \\
\text { Capability level of actors; } \\
\text { E-Government; } \\
\text { Improve situation; } \\
\text { Kapabilitas; } \\
\text { Partisipasi. }\end{array}$ & $\begin{array}{l}\text { Abstract: Does Flexible Process Workflow Play a Role in } \\
\text { Determining Public Value?. This study examines the effect of } \\
\text { improve situation, capability level of actors, and flexible process } \\
\text { workflow on public value. Multiple linear regression was used as } \\
\text { a method, with the selected respondents being people who had } \\
\text { done permit processing and used e-government in Sungai Penuh }\end{array}$ \\
\hline $\begin{array}{l}\text { Keywords: } \\
\text { Capability level of actors; } \\
\text { Capability; } \\
\text { E-Government; } \\
\text { Improve situation; } \\
\text { Participation. }\end{array}$ & $\begin{array}{l}\text { City. The results of the study prove that the public value of e- } \\
\text { government projects is influenced by the improve situation and } \\
\text { capability level of actors. flexible process workflow cannot affect } \\
\text { public values. The results of this study found that community } \\
\text { participation is required for e-government projects. This } \\
\text { participation is not only in use but preferably also at the planning } \\
\text { and development stages. }\end{array}$ \\
\hline
\end{tabular}

\section{INFO ARTIKE}

Nomor 2

Halaman 77-88

ISSN: 2339-1847

e-ISSN: 2683-9968

Kronologi Artikel:

Tanggal Masuk:

Tanggal Revisi:

16 Agustus 202

Tanggal Diterima:

Kata Kunci:

Capability level of actors;

overnment;

Kapabilitas;

Keywords:

Capability level of actors;

Capability;

Improve situation,

ination.

\begin{abstract}
Abstrak: Apakah Flexible Process Workflow Berperan tingkat improve situation, capability level of actors, dan flexible process workflow terhadap nilai publik. Regresi linier berganda masyarakat yang pernah melakukan pengurusan izin dan penelitian membuktikan nilai publik dari proyek e-government dipengaruhi oleh improve situation dan capability level of actors. dibutuhkan proyek e-government. Partisipasi ini bukan hanya dalam penggunaan tetapi sebaiknya juga pada tahap encanaan dan pengembangan.
\end{abstract} \begin{abstract}
Determining Public Value?. This study examines the effect of improve situation, capability level of actors, and flexible process workflow on public value. Multiple linear regression was used as done permit processing and used e-government in Sungai Penuh City. The results of the study prove that the public value of $e$ public values. The results of this study found that community participation is not only in use but preferably also at the planning and development stages.
\end{abstract}

Disitasi sebagai: Intania, A., Rahayu, S \& Kusumastuti, R. YT. (2021). Apakah Flexible Process Workflow Berperan menentukan Nilai Publik?. IMANENSI: Jurnal Ekonomi, Manajemen, dan Akuntansi Islam, 6(2), 77-88. https://doi.org/10.34202/imanensi.6.2.2021.77-88.

\section{PENDAhUluaN}

Indonesia mulai menerapkan e-government mulai dari Tahun 2001, hal ini ditandai dengan Presiden mulai memerintahkan Pengembangan dan Pendayagunaan Telematika Di Indonesia yang dituang dalam Instruksi No. 6/2001 tanggal 24 April 2001 tentang. Instruksi ini mengatur tentang pemanfaatan teknologi telematika yang diwajibkan bagi aparat pemerintah untuk mendorong terwujudnya good governance dan peningkatan demokrasi (Putra, et.al., 2018). Penerapannya dapat dilihat salah 
satunya dari Peringkat EGDI (E-Government Development Index) yang diperoleh dari hasil survei. Peringkat EDGI tahun 2020 telah dipublikasikan dan menunjukkan Indonesia berada pada posisi ke-88 mengalami peningkatan 19 peringkat lebih tinggi dari pada Tahun 2018 dan 28 peringkat dibandingkan Tahun 2016. Pada Tahun 2018, posisi Indonesia masih tertinggal dibandingkan negara-negara ASEAN (Widowati, 2018).

Domain dan website pemerintah menjadi bagian wujud transparansi dan akuntabilitas pengelolaan kegiatan pemerintah, termasuk dalam pengelolaan keuangan daerahnya. Dari sisi keuangan, pemerintah memang sangat penting meningkatkan manajemen keuangan daerahnya untuk meningkatkan akuntabilitas (Rahayu et al., 2018). Pratiwi (2018) membuktikan semua daerah Kota dan Kabupaten di Jambi telah memiliki e-government, walaupun dalam penerapannya masih perlu ditingkatkan pemanfaatannya. Sofyani \& Dwirama (2018) membuktikan bahwa website pemerintah daerah di Indonesia belum menyediakan informasi penting dan cukup bagi publik. Kondisi ini ditunjukkan dengan website aktif pemerintah daerah hanya menyediakan informasi yang masih sangat terbatas dan terkadang juga masih sulit diakses informasinya. Fenomena ini menunjukkan bahwa sebagian besar domain pemerintah daerah masih diterapkan pada tingkat pada tingkat awal masih perlu terus menuju tahap pemantapan sehingga dapat optimal untuk dimanfaatkan pengguna. Hal ini seperti ini juga ditemukan oleh Sari \& Winarno (2012) bahwa e-government di Indonesa sudah menunjukkan perkembangan dari sisi kuantitas namun belum cukup memadai dari sisi kualitas.

Nilai publik secara konseptual merupakan struktur yang bersifat multidimensi dapat dijadikan sebagai cermin yang menggambarkan ekspresi secara kolektif bukan hanya diciptakan sebagai suatu hasil tapi merupakan gambaran proses sehingga memunculkankan kepercayaan dan kesetaraan (O'Flynn, 2007; Broucker, Wit \& Verhoeven, 2018). Dari sudut pandang masyarakat nilai publik dapat meningkatkan kepercayaan, partisipasi dan nilai sosial pemerintah (Mellouli, Bouaziz \& Bentahar, 2020). Nilai publik dapat dipandang sebagai prinsip yang diharapkan suatu pedoman sehingga dapat mengatur dan memberi arahan kepada sikap dan perilaku pegawai dalam menghasilkan layanan publik (Habibullah, 2010). Hal utama yang ingin dicapai dari pemanfaatan teknologi dalam layanan publik atau sering kita sebut juga sebagai e-government berupa kepuasan bagi pelanggan atau pengguna jasa (Habibullah, 2010). Layanan publik itu sendiri merupakan produk yang memerlukan usaha dari manusia sebagai aktor membutuhkan peralatan dan sifatnya tidak kasat mata (Pratama, 2015). Dalam penyediaan layanan publik $e$ government, pemerintah sangat membutuhkan dukungan berupa partisipasi dari masyarakat. Bukan hanya berada pada posisi pengguna aplikasi, masyarakat juga bisa berperan sebagai evaluator. Sehingga diharapkan terjadi hubungan timbal balik yang dapat meningkatkan kualitas layanan, yang akhirnya menjadi nilai publik yang diperoleh dari layanan yang tersedia untuk masyarakat.

Layanan pemerintah perlu berinovasi dan kreatif untuk mampu menghadirkan nilai publik sesuai kebutuhan masyarakat dari layanan yang diberikan. Pemerintah juga harus mampu beradaptasi mengikuti kebutuhan dan tujuan publik yang bersifat dinamis (Muhaimina, 2018). Improve Situation memiliki hubungan dengan peningkatan kualitas pelayanan publik (Quality of Public Service) baik dengan menggunakan e-goverment maupun pelayanan publik secara langsung.

Capability Level of Actors memiliki keterkaitan dengan indikator Competence of Public Organisations pada Nilai publik. Layanan pemerintah perlu berinovasi dan kreatif untuk mampu menghadirkan nilai publik sesuai kebutuhan masyarakat dari layanan yang diberikan. Top dan midle management pemerintah harus terus 
berusaha melakukan inovasi dan kreativitas dalam menawarkan jasa layanan (Moore, 1995). Pemerintah juga harus mampu beradaptasi mengikuti kebutuhan dan tujuan publik yang bersifat dinamis. Langenre (2017) juga menyebutkan kemampuan pegawai yang rendah akan memiliki sikap mengarah pada resisten terhadap perubahan. Gupta \& Suri (2017) membuktikan karyawan dengan keterampilan yang lebih baik dalam berkomunikasi, tingkat pengetahuan, orientasi pelayanan, diharapkan kontribusi terhadap nilai publik ditingkatkan. Selain itu, Flexible Process Workflow memiliki keterkaitan dengan indikator Achievement of Socially Required Outcomes pada nilai publik. Kemudahan akses akan meningkatkan kinerja e-government (Mellouli et al., 2020).

Keterbaruan penelitian ini adalah melihat perspektif masyarakat terhadap implementasi e-government. Penelitian-penelitian sebelumnya masih banyak yang mengeksplorasi dari sudut pengguna internal organisasi dan operator sistem. Peneliti berharap dapat berkontribusi untuk pengembangan e-government ke depannya. Nilai publik dari persepktif masyarakat dapat digunakan sebagai salah satu pertimbangan untuk pengembangan kebijakan. Suatu aplikasi yang memiliki nilai guna tinggi bagi penggunanya akan lebih cepat diterima dan lebih diminati untuk digunakan. Teknologi tersebut harus memberikan kenyamanan, kemudahan, bantuan, dan fleksibilitas, untuk warga juga penting untuk pelayanan yang efektif. Implementasi e-government diharapkan mempercepat proses penataan sistem pelayanan, proses kerja dan manajemen termasuk pengelolaan keuangan pada seluruh organisasi pemerintahan. Pemanfaatan teknologi informasi mampu mewujudkan terciptanya akuntabilitas, transparansi, efisiensi dan efektivitas, yang akhirnya juga akan meningkatkan partisipasi masyarakat karena naiknya tingkat kepercayaan masyarakat (Heryana \& Dewi, 2013). Tujuan penelitian ini melakukan pengujian secara empiris tentang pengaruh dari improve situation, capability level of actors dan flexible process workflow terhadap nilai publik dari penerapan egovernment yang dilihat dari sudut pandang masyarakat.

\section{METODE}

Variabel bebas/independen yang digunakan peneliti yaitu Improve Situation, Capability Level of Actor, Flexible Process Workflow sedangkan variabel dependen adalah Nilai Publik. Regresi Multipel digunakan untuk Analisis data, yang didasarkan pada hubungan kausalitas atau fungsional variabel independent/bebas yang berjumlah satu atau lebih terhadap variabel dependen/ terikat (Sugiyono, 2017). Persamaan regresi yang digunakan sebagai berikut:

$$
\mathrm{Y}=\mathrm{a}+\beta 1 X_{1}+\beta 2 X_{2}+\beta 3 X_{3}+e
$$

Keterangan:

Y : Nilai Publik

a : Konstanta

$\beta 1, \beta 2, \beta 3$ : Koefisien Regresi

$X_{1}$ : Improve Situation

$X_{2}$ : Capability Level of Actors

$X_{3}:$ Flexible Process Workflow

$e:$ Error

Responden yang dipilih peneliti adalah masyarakat Kota Sungai Penuh yang telah mengajukan perizinan melalui laman pemerintah Sungai Penuh. Berdasarkan informasi pengunjung yang tercatat pada tanggal 13 maret 2020 sebanyak 2256 
orang. Masyarakat yang telah mengajukan perizinan sebanyak 370 orang. Peneliti menetapkan accidental sampling sebagai metode pengambilan sampel, kriteria responden, yaitu: 1) Masyarakat telah mengajukan perizinan lewat laman http://sungaipenuhkota.sicantik.layanan.go.id/. Alasan dipilihnya masyarakat Kota Sungai Penuh yang telah mengajukan perizinan tersebut dikarenakan masyarakat yang telah mengajukan lebih memahami bagaimana pelayanan yang diberikan daripada masyarakat yang belum mengajukan website tersebut. Masyarakat yang telah mengajukan perizinan sebanyak 355 orang; 2) Masyarakat yang perizinannya telah diterbitkan. Perizinan yang telah diterbitkan sabanyak 15 orang.

Setiap peneliti mengharapkan data yang representatif dari sampel yang digunakan dalam penelitiannya. Penetapan jumlah sampel sangat tergantung kepada tingkat ketepatan yang diinginkan dari penelitian, sifat (kesamaan atau keragaman) populasi, analisis data yang diinginkan, keterbatasan waktu biaya dan tenaga peneliti. Sugiyono (2017) mengungkapkan bahwa besar kecilnya sampel dapat didasarkan oleh 1) Kebanyakan penelitian tepat untuk menggunakan sampel dengan ukuran lebih dari 30 responden sampai dengan 500 responden; 2) Penelitian multivariat (salah satunya analisis regresi multipel), ukuran sampel dapat ditentukan dengan beberapa kali jumlah variabel penelitian umumnya digunakan sepuluh kali lebih banyak dari jumlah variabel.

Penelitian ini menggunakan dasar penetapan sampel dari Sugiyono (2017) dan ditetapkan jumlah sampel minimal adalah 30 responden. Namun untuk menghindari tingkat pengembalian kuesioner yang rendah maka peneliti menetapkan jumlah kuesioner yang disebarkan kepada 70 responden. Peneliti melakukan pengumpulan data mulai dari tanggal 1 juli 2020 sampai dengan 25 juli 2020. Peneliti melakukan cara pengumpulan data dengan langsung menyerahkan kuesioner kepada para pengguna layanan. Data pengguna e-government di peroleh dari Dinas Pelayanan Modal, Perizinan Terpadu Satu Pintu dan Tenaga Kerja Kota Sungai Penuh. Dari penyebaran 70 kuesioner tercatat responden yang mengurus perizinan dengan rentang usia 30 tahun sampai 47 tahun. Dengan jumlah responden wanita 36 orang dan responden pria 34 orang. Data dikumpulkan melalui kuesioner.

Variabel penelitian ini diukur dengan menggunakan Skala likert. Responden diminta memilih satu dari lima pilihan jawaban disediakan mulai dari sangat setuju sampai dengan pilihan jawaban sangat tidak setuju. Sekaran (2006) menyatakan bahwa skala likert dengan lima pilihan jawaban termasuk skala interval. Peneliti menggunakan indikator yang dikembangkan oleh Gupta \& Suri (2017). Variabel nilai publik mencerminkan opini masyarakat pengguna jasa e-government. Indikatorindikator tersebut terdiri dari ketepatan dan relevansi informasi yang disajikan, kemudahahan akses, kenyamanan pengguna, kecepatan layanan maupun jaringan dan isi serta tampilan yang disediakan dalam aplikasi yang dimanfaatkan oleh pengguna. Selain itu juga, pengguna juga diminta opini terkait layanan terhadap keluhan dan pertanyaan pengguna.

Delapan indikator digunakan peneliti untuk variabel improve situation yang mencakup jarak pengguna ke pusat layanan penggunaan perantara dan ketersediaan fasilitas layanan untuk menunggu pemanfaatan aplikasi untuk pengguna yang menggunaka peralatan di kantor pemerintah. Variabel capability level of actor diturunkan ke enam indikator yang mencerminkan kemampuan karyawan dalam berkomunikasi, kecepatan dan ketepatan kerja, tingkat pengetahuan terhadap layanan, penerapan nilai-nilai etika serta ketepatwaktuan layanan. Variabel flexible process workflow dicerminkan dengan lima indikator yaitu fleksibelitas tepat waktu, layanan tanpa jaringan, ketersediaan pilihan antara manual atau aplikasi, fleksibelitas dalam penerapan dari setiap pusat layanan dalam 
kota dan pemanfaatan oleh pengguna tanpa mengunjungi pusat layanan. Peneliti menilai keeratan hubungan antar variabel independen terhadap variabel dependen, digunakan kriteria dari koefisien korelasi yang dapat dilihat pada Tabel 1.

Tabel 1. Pedoman Interprestasi Terhadap Koefisien

\begin{tabular}{ccc}
\hline No & Interval & Tingkat Hubungan \\
\hline 1 & $0,00-0,20$ & Sangat Lemah \\
2 & $0,21-0,40$ & Lemah \\
3 & $0,41-0,70$ & Kuat \\
4 & $0,71-0,90$ & Sangat Kuat \\
5 & $0,91-0,99$ & Sangat Kuat Sekali \\
6 & 1 & Sempurna \\
\hline
\end{tabular}

\section{HASIL DAN PEMBAHASAN}

Peneliti melakukan pengujian kualitas data terlebih dahulu sebelum melakukan pengujian hipotesis. Peneliti menetapkan tingkat signifikasi sebesar 0,05. Uji validitas dilaksanakan peneliti dengan Pearson Correlation, sedangkan uji reliabilitas menggunakan cronbach alpa, dengan nilai lebih dari 0,6. Hasil uji kualitas data menunjukkan bahwa keseluruhan indikator yang tertuang dalam pernyataan yang dijawab oleh responden memenuhi kriteria untuk dinyatakan valid dan reliabel. Uji $\mathrm{f}$ digunakan peneliti untuk menilai model penelitian, hasilnya menunjukkan bahwa nilai $p$ value sebesar 0,000, nilai ini lebih kecil dari 0,05 , artinya model penelitian ini dapat dikatakan layak atau diterima. Hasil pengujian regresi multipel dapat dilihat pada Tabel 2.

Tabel 2. Hasil Analisis Regresi Multipel

\begin{tabular}{|c|c|c|c|c|}
\hline \multirow{2}{*}{ Variabel } & \multicolumn{2}{|c|}{ Unstandardized Coefficients } & \multirow{2}{*}{$\mathrm{t}$} & \multirow{2}{*}{ Sig } \\
\hline & $\mathrm{B}$ & Std. Error & & \\
\hline Constant & 12,911 & 13,640 & 0,947 & ,347 \\
\hline Improve_Situation & 2,237 & 0,500 & 4,470 & ,000 \\
\hline Capability_Level of Actor & 1,482 & 0,374 & 3,962 & ,000 \\
\hline Flexible_Process_Workflow & $-0,661$ & 0,667 & $-0,991$ & ,352 \\
\hline
\end{tabular}

Ouput SPPS pada Tabel 2 yang merupakan hasil analisis regresi multiple, diperoleh persamaan regresi sebagai berikut

$$
\mathrm{Y}=12,911+2,237 \mathrm{X} 1+1,482 \mathrm{X} 2-0,661 \mathrm{X} 3+\mathrm{e}
$$

Persamaan tersebut dapat diinterprestasikan bahwa konstanta sebesar 12,911, angka ini memiliki makna yaitu apabila Improve Situation (X1), Capability Level of Actor (X2), dan Flexible Process Workflow (X3) diasumsikan = 0, maka opini masyarakat secara konstan bernilai 12.991. Koefisien regresi variabel Improve Situation (X1) sebesar 2,237 menunjukkan arah positif dari opini masyarakat. Hal ini menunjukkan bahwa dengan apabila improve situation meningkat maka akan terjadi peningkatan nilai publik pengguna e-government. Koefisien regresi variabel Capability Level of Actors (X2) sebesar 1,482 memberi arti bahwa Capability Level of Actors secara positif akan meningkatkan nilai publik yang berasal opini masyarakat pengguna e-government. Koefisien regresi variabel Flexible Process Workflow (X3) sebesar - 0,661 menunjukkan arah negative, maknanya peningkatan improve 
situation yang dicerminkan dengan Flexible Process Workflow justru akan menurunkan nilai publik yang berasal dari opini masyarakat pengguna e-govenment.

Nilai Koefisien determinasi $\left(R^{2}\right)$ merupakan nilai yang dapat digunakan untuk menilai kemampuan model dalam menerangkan variasi varibel independen. Hasil pengujian koefisien determinasi disajikan pada Tabel 3.

Tabel 3. Hasil Uji Determinasi

\begin{tabular}{cccc}
\hline $\mathrm{R}$ & $\mathrm{R}^{2}$ & Adjusted $\mathrm{R}^{2}$ & Standard Error of the Estimate \\
\hline 0,694 & 0,481 & 0,458 & 7,34831 \\
\hline
\end{tabular}

Hasil output SPSS menunjukkan nilai koefisien determinasi yaitu berupa Adjusted $R^{2}$ sebesar 0,458 atau $45,8 \%$. Angka ini memiliki makna baha seluruh variabel independen mampu menjelaskan variabel nilai publik sebesar 45,8\%. Angka ini termasuk dalam kelompok kuat karena berada pada interval 41-70\%. Selisihnya yaitu sebesar $54,2 \%$ dapat dijelaskan oleh variabel-variabel diluar model penelitian ini. Variabel lain yang dapat digunakan oleh peneliti selanjutnya sebagai variabel independent yaitu antara lain dukungan legislatif, ketersediaan infrastruktur, gaya kepemimpinan, komitmen top manajemen dan budaya organisasi.

Tabel 4. Hasil Uji Hipotesis

\begin{tabular}{lccc}
\multicolumn{1}{c}{ Variabel } & T & Sig & Kesimpulan \\
\hline Improve_Situation & 4,470 &, 000 & Berpengaruh \\
Capability_Level of Actor & 3,962 &, 000 & Berpengaruh \\
Flexible_Process_Workflow & $-0,991$ &, 352 & Tidak Berpengaruh \\
\hline
\end{tabular}

Hasil pengujian setiap variabel ditunjukkan dari hasil Uji t. Peneliti menyajikan hasil uji t pada Tabel 4. Berdasarkan ringkasan hasil Tabel 4, terdapat satu variabel yang tidak terbukti berpengaruh terhadap nilai publik yaitu flexible process workflow, sedangkan kedua variabel terbukti berpengaruh dalam meningkatkan nilai publik.

\subsection{Pengaruh Improve Situation terhadap Nilai Publik}

Improve situation secara statistik menunjukkan berpengaruh terhadap nilai publik. Hal tersebut ditunjukkan tingkat $p$ value $=0,000$ untuk variabel Improve Situation. Angka ini berada dibawah tingkat signifikansi yang ditentukan atau lebih kecil dari 0,05. Hasil perhitungan ini membuktikan bahwa hipotesis 1 terbukti dapat diterima artinya Improve Situation berpengaruh terhadap Nilai Publik.

Improve situation memiliki nilai positif dari opini masyarakat. Improve situation berkaitan dengan usaha pemerintah untuk memberikan layanan bagi para pengguna e-government agar merasa nyaman. Pemerintah Kota Sungai Penuh termasuk salah satu daerah di Provinsi Jambi yang aktif dalam menerapkan e-government. Status penerapan e-government dan situs web Kota Sungai Penuh dan Kabupaten serta Kota di Provinsi Jambi pada Tabel 5 menggambarkan bahwa 75\% website milik pemerintah Kota dan Kabupaten di Provinsi Jambi pada posisi aktif, namun masih dua daerah yaitu Kabupaten Sarolangun dan Kabupaten Tebo pada posisi "under restriction". 
Kota Sungai Penuh telah menyediakan jasa pelayanan publik terkait perizinan dan penanaman modal secara on line. Proses layanan untuk perizinan yang diberikan oleh Dinas Pelayanan Modal, Perizinan Terpadu Satu Pintu dan Tenaga Kerja di Kota Sungai Penuh telah dilakukan melalui website resmi. Aplikasi yang tersedia disebut SiCANTIK (Aplikasi Cerdas Layanan Terpadu Untuk Publik). Posisi per 13 Maret 2020 terdapat 2.256 orang pengunjung yang membuka situs ini. Terdapat 355 nomor pendaftaran yang masih berada dalam proses.

Tabel 5. Status dan Situs Web Kabupaten/Kota di Provinsi Jambi

\begin{tabular}{clcc}
\hline No & \multicolumn{1}{c}{ Kabupaten/Kota } & Situs Web & Status \\
\hline 1 & Kab. Kerinci & kerincikab.go.id & Aktif \\
2 & Kab. Merangin & meranginkab.go.id & Aktif \\
3 & Kab. Sarolangun & sarolangunkab.go.id & Under restriction \\
4 & Kab. Batanghari & batangharikab.go.id & Aktif \\
5 & Kab. Muaro Jambi & muarojambikab.go.id & Aktif \\
6 & Kab. Tanjung Jabung Barat & tanjabbarkab.go.id & Aktif \\
7 & Kab. Tanjung Jabung Timur & tanjabtimkab.go.id & Aktif \\
8 & Kab. Muaro Bungo & bungokab.go.id & Aktif \\
9 & Kab. Tebo & tebokab.go.id & Under restriction \\
10 & Kota Jambi & jambikota.go.id & Aktif \\
11 & Kota Sungai Penuh & sungaipenuhkota.go.id & Aktif \\
\hline
\end{tabular}

Sumber: Pratiwi (2018)

Hasil survei pengguna web berdasarkan ulasan dari pengunjung untuk Tahun 2019 sebagaimana Tabel 6 menunjukkan rata-rata kinerja unit pelayanan dari sudut pandang pengguna sudah baik, bahkan terdapat dua item yang berada pada posisi sangat baik. Kualitas layanan ini perlu terus ditingkatkan karena pengurusan proses perizinan SiCANTIK pada Dinas Penaman Modal Pelayanan Terpadu Satu Pintu dan Tenaga Kerja (DPMPTSPTK) ini akan menambah pemasukan ke pajak daerah.

Data hasil survei pada Tabel 6 sesuai dengan hasil penelitian ini yang menunjukkan bahwa rata-rata dari penilaian kuesioner, Improve Situation memiliki nilai 3,8 yang dapat dikatakan bahwa hal ini dapat diartikan bahwa masyarakat memberikan opini tentang layanan yang diterima terkait e-government sudah baik. Pemerintah Kota Sungai Penuh harus terus melakukan improvisasi dalam berbagai hal untuk lingkungan dan fasilitas fisik seperti kebersihan, kemudahan akses dan kenyamanan ruang tunggu. Beberapa kondisi yang masih perlu ditingkatkan seperti tersedianya ruangan berpendingin dan ketersediaan air minum untuk pengunjung. Hasil penelitian ini sejalan dengan Gupta \& Suri (2017) yang membuktikan bahwa improve situation berpengaruh terhadap nilai publik dari e-government dari persepsi masyarakat. Ketersediaan tempat akses yang nyaman dan mudah dijangkau menjadi salah satu faktor penentu untuk keberhasilan e-government (Sari \& Winarno, 2012). Improve situation ini juga dapat dijadikan indikator kualitas layanan bagi pengguna dari sisi fasilitas fisik yang tersedia.

\subsection{Pengaruh Capability Level of Actors dengan Nilai Publik}

Variabel Capability Level of Actors secara statistik menunjukkan adanya pengaruh terhadap nilai publik. Hal tersebut terbukti tingkat $p$ value $=0,000$ untuk variabel Capability Level of Actors berada di bawah tingkat signifikansi. Peneliti menetapkan batasan sebesar 0,05, sehingga hipotesis 2 terbukti atau diterima, artinya Capability Level of Actors berpengaruh terhadap Nilai Publik. 
Tabel 6. Hasil Survey Kepuasan Penguna atas Layanan DPMPTSPTK

\begin{tabular}{|c|c|c|c|c|}
\hline No & Unsur Pelayanan & Indeks & Mutu & Kinerja \\
\hline 1 & $\begin{array}{l}\text { Persyaratan Teknis dan } \\
\text { Administrasi }\end{array}$ & 88,67 & A & Sangat Baik \\
\hline 2 & Prosedur Pelayanan & 82 & $\mathrm{~A}$ & Sangat Baik \\
\hline 3 & Waktu Pelayanan & 81,17 & $\mathrm{~B}$ & Baik \\
\hline 4 & Biaya Pelayanan & 81,17 & $\mathrm{~B}$ & Baik \\
\hline 5 & $\begin{array}{l}\text { Produk Spek. Jenis } \\
\text { Pelayanan }\end{array}$ & 80,33 & B & Baik \\
\hline 6 & Kompetensi Petugas & 80,17 & B & Baik \\
\hline 7 & Perilaku Petugas & 79,5 & $\mathrm{~B}$ & Baik \\
\hline 8 & Maklumat Pelayanan & 79 & B & Baik \\
\hline \multirow[t]{2}{*}{9} & Penanganan Pengaduan & 79 & B & Baik \\
\hline & Rata-Rata Keseluruhan & 81,22 & B & \\
\hline
\end{tabular}

Sumber: (DPMPTSPTK Kota Sungai Penuh, 2019)

Hasil penelitian ini menunjukkan bahwa Capability level of actors memiliki nilai positif dari opini masyarakat, sesuai dengan hasil penelitian Gupta \& Suri (2017). Hal ini menunjukkan bahwa kemampuan pegawai dalam memberikan pelayanan sudah baik. Cara berkomunikasi, kecepatan dalam bekerja, ketepatan waktu saat bekerja, dan menghormati nilai- nilai dan beretika pegawai dapat dikatakan baik. Berdasarkan rata - rata dari opini masyarakat pengguna fasilitas layanan e-government di Kota Sungai Penuh, Capabilty Level of Actors memiliki nilai 4,6 yang dapat dikatakan sudah baik. Artiknya masyarakat memberikan opini kemampuan atau kapabilitas pegawai dalam memberikan layanan pemanfaatan $e-$ government sudah baik. Sumber daya manusia memang menjadi faktor penentu keberhasilan e-government baik dari sisi ketersediaannya (Sari \& Winarno, 2012) maupun kompetensinya (Langenre, 2017).

Kapabilitas sumber daya manusia organisasi sangat berharga, langka, sulit untuk ditiru dan tidak dapat digantikan (Chuang, Liu \& Chen, 2015). Hertati (2015) menjelaskan bahwa sumber daya manusia memiliki peran untuk posisi yang menentukan keberlangsungan suatu institusi. Keberhasilan penerapan sistem informasi dalam suatu organisasi juga ditentukan oleh manusia (Ravichandran, 2005). Sumber daya manusia yang memiliki kapabilitas yang tinggi akan meningkatkan efektivitas organisasi yang akhirnya akan dapat meningkatkan kinerja (Chuang, Liu \& Chen, 2015). Oleh karena itu, komitmen untuk kapabilitas sumber daya manusia menjadi sangat penting diperhatikan baik oleh organisasi swasta maupun pemerintah. Kinerja penerapan sistem informasi memang dipengaruhi oleh kapabilitas sumber daya manusia yang menjalankannya. Kapabilitas seseorang dipengaruhi oleh kompetensi yang dimilikinya. Kapabilitas dan kompetensi memiliki arti yang sama yaitu kemampuan. perbedaannya terletak kepada tingkatan skill atau kemampuan yang dimilikinya. Kapabilitas lebih menunjukkan kemampuan yang mendalam dan lebih mendetail bukan hanya aspek teknis menjalankan saja, tetapi sampai dengan mengetahui titik kelemahan dan menyelesaikan masalah untuk aspek tertentu.

Kompetensi sumber daya manusia juga akan mempengaruhi kinerja pegawai (Nur \& Khair, 2021). Kompetensi dapat didefenisikan sebagai kemampuan seseorang yang dapat dilihat dari aspek pengetahuan, skill dan sikap dalam menyelesaikan pekerjaan atau tugas tertentu sesuai dengan standar tertentu yang telah ditetapkan (Rudana, 2008). Kemampuan yang harus dimiliki bukan hanya terkait teknis pekerjaan saja. Layanan bagi masyarakat juga memerlukan soft skill seperti 
kemampuan komunikasi, sosial dan menjaga stabilitas emosi juga penting untuk dimiliki oleh para aparatur daerah.

Sumber daya manusia juga menjadi penentu keamanan dari sistem informasi yang dibangun (Soni et al., 2017), sehingga perhatian terhadap soft skill juga harus diperhatikan seperti nilai-nilai etika (Gupta \& Suri, 2017). Pemerintah Daerah Kota Sungai Penuh dapat meningkatkan kapabilitas sumber daya manusia aparaturnya melalui pemberian beasiswa studi lanjut, pelatihan, bimbingan teknis dan sosialisasi terkait e-government. Chuang, Liu \& Chen (2015) untuk pengembangan kapabilitas sumber daya manusia maka perlu memperhatikan pelatihan untuk meningkatkan kemampuan, penghargaan atas capaian kinerja dan pengembangan tim kerja. Selain itu, juga perlu dipertimbangkan sosialisasi ke masyarakat yang lebih intensif sehingga dapat mengetahui tentang e-government yang telah dapat dimanfaatkannya. Duta-duta e-government juga bisa menjadi alternatif untuk penyebarluasan informasi ke masyarakat.

\subsection{Pengaruh Flexible Process Workflow dengan Nilai Publik}

Variabel Flexible Process Workflow secara statistik menunjukkan tidak berpengaruh terhadap nilai publik. Hal tersebut terbukti tingkat $p$ value $=0,325$. Angka ini berada diatas tingkat signifikansi yang ditetapkan peneliti yaitu sebesar 0,05, sehingga hipotesis 3 tidak terbukti dapat diterima, artinya Flexible Process Workflow tidak mampu mempengaruhi Nilai Publik. Hasil penelitian ini menunjukkan bahwa Flexible Process Workflow yang dinilai dari opini masyarakat masih perlu ditingkatkan. Hal ini terbukti dari rata-rata nilai persepsi masyarakat untuk variabel ini berada pada nilai 3,3. Pertanyaan yang mendapatkan penilaian terendah untuk proses yang fleksibel adalah pada item ke tiga yaitu ketersediaan pilihan layanan antara manual dan aplikasi online.

Masyarakat masih mengalami kesalahan teknis pada layanan yang terganggu dan pilihan antara manual dan online tidak di sediakan sehingga pada saat terganggunya jaringan internet maka proses layanan juga terhambat. Masyarakat juga memberikan opini yang belum baik untuk item pertanyaan ke empat. Item ini terkait dengan ketersediaan layanan tanpa gangguan jika terjadi kesalahan teknis. Item ini masih memiliki keterkaitan dengan item pertanyaan ketiga. Selain kedua item pertanyaan tersebut, masyarakat juga memberikan rata-rata nilai terendah ke tiga yaitu fleksibilitas tanggal dan waktu pengajuan aplikasi. Kemudahan akses bagi pengguna terhadap fasilitas dan layanan e-government akan dapat meningkatkan nilai publik (Mellouli et al., 2020)

Fleksibilitas berkaitan dengan kecepatan dan kemudahan untuk beradaptasi karena adanya perubahan. Dalam sistem informasi, fleksibilitas merupakan ability dari sistem untuk mengikuti perubahan atau menyikapi kebutuhan serta merespon pengguna dengan memperhatikan persyaratannya. Pengguna biasanya membutuhkan sistem yang berbeda, baru dan berubah (Arafat, 2016) beradaptasi mengikuti kebutuhan. Dalam suatu proses sistem informasi, terdapat empat kebutuhan fleksibilitas utama yaitu dukungan untuk variabilitas, kelonggaran, adaptasi dan evolusi. Setiap kebutuhan fleksibilitas tersebut dapat mempengaruhi perspektir proses dari sisi perilaku, organisasi, informasi, operasi, fungsi dan waktu (Reichert \& Weber, 2012) serta metode dan produk (Arafat, 2016). Aspek metode, produk dan waktu berkaitan dengan arsitektur dan pemeliharaan sistem, sedangkan aspek strategi, proses dan perilaku itu sendiri berkaitan dengan sumber daya manusia (Arafat, 2016).

Sari \& Winarno (2012) menjelaskan beberapa tantangan dalam penerapan $e$ government antara lain dukungan dari legislatif. Dukungan ini terkait dengan persetujuan legislatif untuk pemerintah mengalokasikan anggaran untuk 
infrastruktur harus dikembangkan secara merata, karena membutuhkan anggaran yang cukup banyak. Selain itu juga dibutuhkan anggaran agar bisa memberikan fasilitas dan reward bagi para ahli yang mengembangkan sistem informasi ini. Sosialisasi membiasakan budaya memanfaatkan e-government di masyarakat juga diperlukan agar dapat menciptakan perasaan nyaman dan aman saat menggunakannya. Kegiatan tersebut juga akan mampu meningkatkan intensi pengguna. Intensi pengguna dan kepuasan pengguna sangat penting menentukan penggunaan e-government (Mellouli et al., 2020).

Tugas ini tentu bukan hanya tanggung jawab pemerintah saja, semua unsur baik swasta maupun masyarakat harus dapat mendukung tercapainya pemanfaatan e-government yang baik karena berujung pada kemudahan layanan yang diterima oleh seluruh masyarakat. Oleh karena itu, dalam pengembangan sistem perlu memperhatikan fleksibilitas dalam penggunaan dan fleksibilitas terhadap perubahan (Arafat, 2016). Kesuksesan saat ini tergantung kepada kemampuan untuk tanggap terhadap perubahan lingkungan dengan cepat dan dengan cara yang fleksibel (Reichert \& Weber, 2012).

Penyediaan sarana juga harus diperhatikan, karena tidak semua masyarakat memiliki fasilitas seperti android dan jaringan internet untuk memanfaatkan layanan ini. Keikutsertaan pengguna dalam hal ini masyarakat perlu diperhatikan karena penting dalam implementasi e-government. Keterlibatan masyarakt perlu diperhatikan juga pada tahap perencanaan, evaluasi dan pengembangan, sehingga aplikasi dan layanan yang disediakan benar-benar mengakomodir kebutuhan masyarakat. Masyarakat akan lebih nyaman dan sukarela menggunakannya, bahkan dapat ikut serta mempromosikan penggunaan kepada anggota masyarakat yang lainnya.

\section{SIMPULAN}

Berdasarkan hasil dan analisis yang dibahas sebelumnya maka peneliti menarik kesimpulan secara empiris Improve Situation dan Capability Levelof Actor berpengaruh terhadap Nilai Publik, Namun Flexible Process Workflow tidak berpengaruh terhadap Nilai Publik. Flexible Process Workflow yang dapat mempermudah masyarakat dalam mengakses dan menggunakan e-government masih perlu diperhatikan. Hal ini terjadi karena jaringan internet yang terhambat dan kemungkinan terjadinya kesalahan teknis saat penggunaan. Ketersediaan layanan manual juga perlu diperhatikan untuk antisipasi apabila layanan on line sedang bermasalah.

Hasil penelitian ini berimplikasi aparatur yang memberikan layanan penerapan e-government harus diperhatikan baik dari sisi jumlah maupun kompetensi teknologi informasinya serta soft skillnya. Pemerintah daerah juga harus memperhatikan infrastruktur e-government bukan hanya dari sisi hardware dan software saja tetapi juga fasilitas bagi pengguna yang memanfaatkan layanan tersebut. Partipasi masyarakat perlu ditingkatkan mulai pada tahap perencanaan sampai dengan tahap implementasi dan evaluasi serta pengembangan e-government. Salah satu keterbatasan penelitian ini adalah penggunaan kuesioner tertutup untuk mengumpulkan data, sehingga belum memberikan kesempatan kepada partisipan untuk memberikan penjelasan lebih banyak terkait topik penelitian.

Peneliti berikutnya mempunyai kesempatan untuk mengembangkan hasil penelitian ini dengan metode dan pendekatan penelitian lainnya, seperti pendekatan kualitatif. Pendekatan kualitatif sangat memungkinkan peneliti untuk mengeksplorasi makna dan praktik e-government sehari-hari dalam kegiatan pemerintahan. Peneliti dapat menggunakan masyarakat sebagai partisipan, namun dapat juga melihat dari sudut pandang pengguna internal organisasi perangkat 
daerah. Peneliti berikutnya juga dapat menambah variabel penelitian yang lain seperti gaya kepemimpinan, dukungan legislatif dan budaya organisasi. Subjek penelitian juga dapat diperluas untuk Kabupaten dan Kota di daerah lain serta dapat difokuskan ke e-government untuk pengelolaan keuangan negara.

\section{REFERENSI}

Arafat, Y. (2016). Fleksibilitas Sistem Informasi dari Perspektif Pengguna dan Pengembang Sistem Informasi. Jurnal ELKHA, Vol. 8, No. 1.

Broucker B, Wit K. D. \& Verhoeven J.C. (2018) Higher education for public value: taking the debate beyond New Public Management, Higher Education Research \& Development, 37:2, 227-240, DOI: 10.1080/07294360.2017.1370441

Chuang, Liu \& Chen, 2015, The Effects of Human Resource Capability and Internal Customer Satisfaction on Organizational Effectiveness, International Journal of Distributed Sensor Networks, July 7, https: / / doi.org/10.1155/2015/835194

Gupta, G. J \& Suri, P, (2017). Measuring Public Value of E-Governance Project in India : citizens' perspektive. Transforming Goverment : People, Process and Policy, 11(2), 236-261.

Habibullah, A. (2010). Kajian Pemanfaatan dan Pengembangan E-Govermment. Jurnal Masyarakat,Kebudayaan dan Politik 23(c), 187-195.

Heryana T \& Dewi S. K, 2013, Pengaruh Penerapan e-Government terhadap Pelaksanaan Tata Kelola Pemerintah di Pemerintah Kabupaten Cianjur, Jurnal Riset Akuntansi dan Keuangan, 1, 1, 38-49

Hertati, L. (2015) Competence of Human Resources, The Benefits of Information Tehnologi on Value of Financial Reporting in Indonesia, Research Journal of Finance and Accounting. Vol 6., No. 8.

Kota Sungai Penuh, (2019). Survei Kepuasan Masyarakat Semester 2, Tahun 2019, Dinas Penanaman Modal, Pelayanan Terpadu Satu Pintu dan Tenaga Kerja (DPMPTSPTK) Kota Sungai Penuh: http://dpmptsptk.sungaipenuhkota.go.id/pages/detail_berita.php?id=13

Langenre, S, S., 2017, Pengaruh Kapasitas Sumber Daya Manusia, Pemanfaatan Teknologi Sistem Informasi Manajemen Daerah, Penerapan Standar Akuntansi Pemerintah terhadap Kualitas Laporan Keuangan Daerah (Studi pada SKPD Kabupaten Buol), Jurnal Katalogis, Vol 5, 8, 97-107

Mellouli M, Bouaziz F. \& Bentahar O (2020): E-government success assessment from a public value perspective, International Review of Public Administration, DOI: 10.1080/12294659.2020.1799517

Moore, M. H. (1995). Creating public value. Strategic management in government. Cambridge:Harvard University Press.

Muhaimina. (2018). Public Value (Nilai Publik) dari inovasi Layanan Pengaduan Darurat Commad Center 112 Surabaya. Jurnal Penelitian FISIP. Universitas Airlangga, 5.

Nur. F. \& Khair, H. Pengaruh Kompetensi Sumber Daya Manusia, Sistem Informasi Manajemen dan Keterampilan Kerja terhadap Kinerja Pegawai pada Dinas Kominfo Labuhanbatu Utara, Jurnal Humaniora, Vol. 5 No. 1 April.

O’Flynn J, 2007, From New Public Management to Public Value, Paradigmatic Change and Managerial Implication, Australian Journal of Public Administration, Vol 66, Issue 3, 353-366

Pratama, M. H. (2015). Strategi Meningkatkan Kualitas Pelayanan Publik (Studi Deskriptif tentang Strategi UPTD Pengujian Kendaraan Bermotor Tandes Kota Surabaya dalam Meningkatkan Kualitas Pelayanan Pengujian Kendaraan Bermotor). Kebijakan dan Manajemen Publik 3(3). 
Pratiwi, C. S. (2018). Implementasi E-Goverment pada Situs Web Pemerintah Menuju Tata Kelola Pemerintahan Berbasis Open Goverment di Provinsi Jamvi. Jurnal Khazanah Intelektual 2(1), 109-126.

Putra, R., Oryza, A, Rahma, R.W \& Berlina Y.P, (2018), Evaluasi Perkembangan Dan Transparansi Laporan Keuangan Pemerintah Daerah di Indonesia, Artikel dipublikasikan pada seminar nasional teknologi informasi dan komunikasi Tahun 2018, Yogyakarta 23-24 Maret 2018

Rahayu, S., Yudi \& Rahayu, (2018), How to Improve Accountability of Fixed Asset of Local Government? Jurnal Persepektif dan Pembiayaan Daerah, Vol 6 No. 2, September-October.

Rahichandran, T, (2005). Effect of Information Systems Resources and Capabilities on Firm Performance: A Resource-Based Perspective, Journal of Management Information Systems 21(4):237-276

Reichert. M, \& Weber, B, (2012), Enabling Flexibility in Process-Aware Infromation System: Challenges, Methods, Technology, Springer-Verlag, Berlin Heidelberg.

Rudana, Nyoman. (2008). Effect of Local Government Officials Competence and Interpersonal Communication on the quality of public services in the Office of the Gianyar regency. Http://dacribd.com/docs/28dbzlnf xglfihje5rei.pdf)

Sari, A. D \& Winarno A, (2012), Implementasi e-Government System dalam Upaya Peningkatan Clean dan Good Governance di Indonesia, JEAM, Vol 11, No. 1

Sekaran, U, (2006), Research Method for Business (Metodologi Penelitian untuk Bisnis), Buku 2, Edisi 4, Salemba Empat, Jakarta

Soni V, Prasanta Kumar Dey, Rashmi Anand, Charru Malhotra, Devinder Kumar Banwet, (2017) Digitizing grey portions of e-governance", Transforming Government: People, Process and Policy, Vol. 11 Issue: 3, pp.419-455, https://doi.org/10.1108/TG-11-2016-0076

Sugiyono. (2017). Metode Penelitian Kuantitatif, Kualitatif, dan R\&D. Bandung: Alfabeta

Sofyani, H., \& Dwirama, V. (2018). Determinants financial and-non-financial information disclosure in Indonesian local government. Yogyakarta: Universitas Muhammadiyah Yogyakarta, Indonesia.

Widowati, D. P. (2018, 08 23). survei-pbb-2018-peringkat-e-government-indonesia. Dipetik 06 22, 2020, dari bpptik.kominfo.go.id: https:/ / bpptik.kominfo.go.id/2018/08/23/5938/survei-pbb-2018-

peringkat-e-government-indonesia/ 